\title{
Migratory bird species in young tropical forest restoration sites: effects of vegetation height, planting design, and season
}

\author{
CATHERINE A. LINDELL, REBECCA J. COLE, KAREN D. HOLL \\ and RAKAN A. ZAHAWI
}

\section{Summary}

Tropical land cover change has negatively affected numerous migratory bird populations. Forest restoration can augment migrant wintering habitat. However, almost no information exists about factors that influence migrant use of tropical restoration sites. We sampled migrant birds in young restoration sites in Costa Rica from February 2006 to April 2008 to determine how vegetation height, planting design, season, and landscape forest cover influenced capture rates of four declining species. We also documented total numbers of migratory species and individuals captured in each planting design treatment; each site had a control treatment where seedlings were not planted, an island treatment where seedlings were planted in patches, and a plantation treatment where seedlings were planted to cover the entire area. Sites varied in landscape forest cover within $500 \mathrm{~m}$ buffers. Three out of four focal species were captured significantly more often in plantation treatments than island or control treatments. Two of the four species showed seasonal patterns and one species was captured more often in high-vegetation sites. Greater numbers of species and individuals were captured in plantation treatments compared to island and control treatments. The plantation planting design increased migrant use more quickly than the island planting design. When resources are available, we recommend planting plantation-style to rapidly increase the value of restoration sites to a range of species, particularly those that use woody vegetation. When resources are more limited, planting islands may be a cost-effective, although not as ecologically effective, alternative that supports a diversity of migrant species compared to unplanted controls.

\section{Resumen}

En los trópicos, los cambios en la cobertura de la vegetación han afectado negativamente a las poblaciones de aves migratorias. La restauración forestal puede incrementar el hábitat utilizable durante la época invernal. No obstante, casi no hay información respecto a los factores que determinan la selección de sitios por las especies migratorias. Durante febrero del 2006 a abril del 2008, muestreamos especies migratorias en sitios jovenes de restauración forestal en Costa Rica. El objetivo fue determinar cómo la altura de la vegetación, el tipo de plantación, la estación del año, y la cobertura de bosque en el paisaje influían las tasas de captura de cuatro especies en estado de declinación. Contabilizamos asimismo el número de individuos capturados de otras especies migratorias presentes. En cada sitio de observación plantas de semillero se plantaron para configurar tres tipos de cobertura de árboles: a) un tratamiento sin árboles (control), b) un tratamiento de cobertura fragmentada (islas de árboles), y c) un tratamiento de cobertura total. La cobertura forestal alrededor de los sitios (en un radio de $500 \mathrm{~m}$ ) fue variable. De las cuatro especies migratorias de interés, tres fueron capturadas (significativamente) con más frecuencia en el tratamiento de cobertura total. Dos especies mostraron 
patrones estacionales, y una especie se capturó más frecuentemente en sitios de vegetación alta. El número de especies e individuos capturados de otras aves migratorias también fue mayor en el tratamiento de cobertura total. En general el tratamiento de cobertura total incremento el número de especies migratorias con respecto al tratamiento de cobertura fragmentada. Proveer refugios a las aves migratorias a través de manchones o islas de arboles quizás sea una alternativa rentable. Sin embargo, y en la medida que los recursos lo permitan, es más efectivo desde un punto de vista ecológico el reducir la fragmentación del paisaje proveyendo con vastas áreas de cobertura forestal las cuales pueden sustentan una mayor diversidad de especies migratorias.

\section{Introduction}

The world's forests continue to decrease in extent, resulting in vast areas of degraded lands (FAO 2005). Tropical land cover change is predicted to threaten the survival of many species in coming years (Dirzo and Raven 2003). Active forest restoration is increasingly important to counter present trends (Lamb et al. 2005, Chazdon 2008).

More than 10\% of migratory bird species are classified as threatened or near-threatened by BirdLife International (Kirby et al. 2008). Previous work indicates that land cover change on tropical wintering grounds has negatively affected migrant populations (Robbins et al. 1989, Newton 2004, Norris et al. 2004, Holmes 2007). However, despite calls to investigate strategies to improve tropical lands for migrant use (Greenberg 1992a) migrant responses to tropical restoration efforts are virtually unexplored (Reid et al. 2008).

Bird habitat use is driven by environmental characteristics on a number of scales, from the micro-scale, to the patch scale, to the landscape scale (Hutto 1985). We considered patch and landscape scales in this study by comparing migrant captures in $50 \times 50 \mathrm{~m}$ plots with different planting designs and surrounded by landscapes that varied in forest cover. This plot size is often the focus of restoration efforts (e.g. Chapman and Chapman 1999, Zahawi and Augspurger 2006) and birds show ecological and behavioural responses to vegetation patterns at this scale (e.g. Leyequién et al. 2010, Morrison et al. 2010). Recapture data showed the plots were regularly used by individual birds within and across winters, indicating that the plots comprise part, although likely not all, of individuals' winter ranges. Landscape effects on wintering Neotropical migrants have not been previously investigated. However, landscape characteristics have influenced resident birds in restoration contexts (e.g. Lindenmayer et al. 2010) and knowledge of landscape affects could help prioritise sites for restoration.

Planting trees in islands rather than covering an area, plantation-style, has been gaining attention as a restoration planting design because 1 ) islands serve as foci for plant colonisation (Robinson and Handel 2000), 2) it is more cost-effective to plant and maintain tree seedlings in islands rather than over large areas, and 3) island planting may attract a variety of species types (Rey Benayas et al. 2008). However, no previous work has compared planting design effects on migrant use of sites. Our study design provided a high degree of replication; 14 sites were planted with seedlings in three treatments: control (no planting of seedlings), island (planting in islands), and plantation (planting to cover an area). The control treatments resembled active pasture or recently abandoned pasture, which provides poor habitat for most wintering migrants (e.g. Estrada et al. 1997). We assumed controls would have the fewest migrant captures. Greater migrant captures in island treatments compared to plantation treatments would indicate that planting in islands more quickly resulted in habitat that was used by migrants. We did not assume that island or plantation treatments would provide optimal migrant habitat; our focus was on determining which treatment more quickly moved an area from poorquality to better-quality habitat early in the restoration process.

We investigated vegetation height, planting design, season, and land cover effects on the number of captures of four species that, based on Breeding Bird Survey data (Sauer et al. 2008), declined significantly in North America from 1992 to 2007: Chestnut-sided Warbler Dendroica pensylvanica, Mourning Warbler Oporornis philadelphia, Swainson's Thrush Catharus ustulatus, and Tennessee Warbler Vermivora peregrina. We expected that the species with greater 
affinity for woody habitat, Chestnut-sided Warblers and Swainson's Thrushes (Richardson and Brauning 1995, Mack and Wang 2000), would be captured most often in high-vegetation sites in high forest cover landscapes and in plantation treatments. We predicted similar but weaker patterns for Tennessee Warblers because their wintering site use is flexible (e.g. Robbins et al. 1992). Mourning Warblers use densely vegetated habitat like abandoned pasture (Stiles and Skutch 1989). Thus, we did not expect strong effects of vegetation height, planting treatment, or landscape forest cover on captures of this species. We also expected that more migrant species would be captured in plantation and island treatments compared to control treatments and that plantation treatments would be used more by species with affinities for woody vegetation.

\section{Methods}

Study sites

Study sites were in Coto Brus county, Costa Rica, between Agua Buena, $8^{\circ} 44^{\prime} \mathrm{N}, 82^{\circ}{ }_{5} 6^{\prime} \mathrm{W}$ and the Las Cruces Biological Station, $8^{\circ} 47^{\prime} \mathrm{N}, 82^{\circ} 57^{\prime} \mathrm{W}$ (Figure 1). Fourteen sites were planted with four species of tree seedlings, Terminalia amazonia (J.F. Gmel.) Exell [Combretaceae], Vochysia guatemalensis Donn. Sm. [Vochysiaceae], Erythrina poeppigiana (Walp.) O.F. Cook [Fabaceae], and Inga edulis Mart. [Fabaceae]. All species are native or naturalised to the region.

Six sites were planted in 2004, five in 2005, and three in 2006. Because sites were planted in different years and because seedling growth rates varied among sites, vegetation height varied. We classified sites into vegetation height categories (low or high) based on the average height of Inga trees, the fastest growing species, in plantation and island treatments as measured in July 2007: low $=$ mean of $79-332 \mathrm{~cm}(n=10) ;$ high $=490-576 \mathrm{~cm}(n=4)$.

Sites were between $1,050 \mathrm{~m}$ and $1,450 \mathrm{~m}$ in elevation and the majority were $>1.2 \mathrm{~km}$ from each other with two pairs separated by $>600 \mathrm{~m}$. Sites were pasture or sun coffee before being planted and species present included non-native grasses and herbs. All sites were mechanically cleared of vegetation, including coffee plants, before planting.

Each site had three $50 \times 50-m$ treatments or plot types (we use the terms interchangeably): 1) a control plot where no seedlings were planted, 2) a plantation plot where seedlings were planted to cover the entire area, and 3 ) an island plot where seedlings were planted in six islands: two of $4 \times 4 \mathrm{~m}$, two of $8 \times 8 \mathrm{~m}$, and two of $12 \times 12 \mathrm{~m}$. Seedlings were planted $2.8 \mathrm{~m}$ apart. All treatments were cleared of vegetation every few months for the first 2.5 years to allow the seedlings to become established. The matrix in between the islands comprised grasses and herbs, with woody species becoming more common over time (Holl et al. 2011).

\section{Bird sampling}

Permanent mist-net lanes were established along trails in plots. Three nets, $12 \mathrm{~m}$ long and $2.6 \mathrm{~m}$ high, were used in each treatment during a morning of sampling. Nets were opened within $30 \mathrm{~min}$ of sunrise and kept open for five hours, resulting in 15 hours per treatment and a total of 45 hours of sampling per round per site. Nets were closed during rain or high winds. Sampling took place in February 2006 and in the 2006/2007 and 2007/2008 wintering seasons, during November, February, and April for a total of seven sampling rounds. Eight sites were sampled during all seven rounds, five sites during six of the rounds and one site during one round. Birds were identified to species and banded with U.S. Fish and Wildlife Service bands.

\section{Land cover measurements}

We conducted land cover analyses using aerial photographs taken in 1998 (the Terra project) and 2005 (the Carta project) in campaigns sponsored by the Costa Rican government. Most of the classification was made with the 2005 photos, collected during March and April 2005, at a scale of 


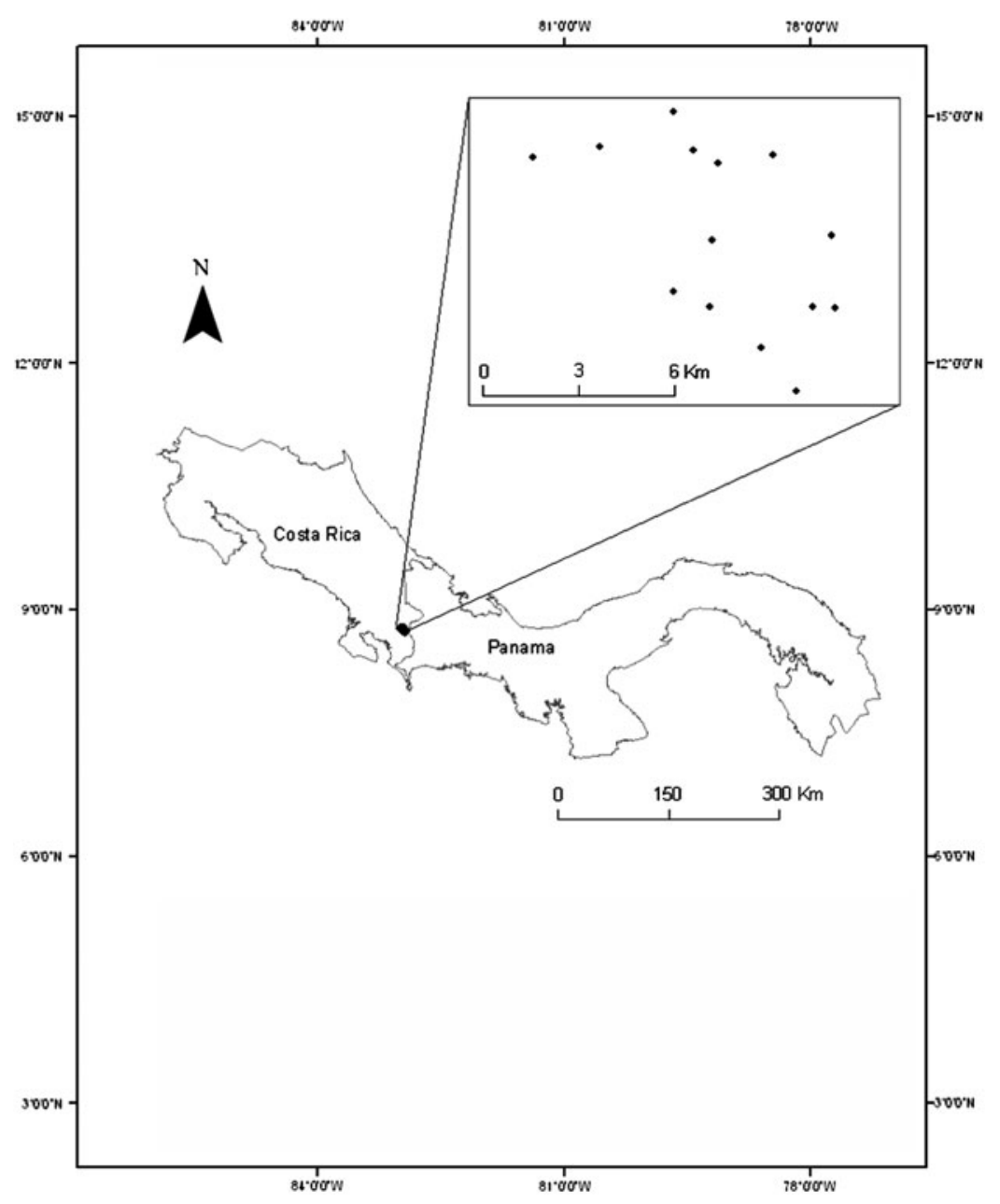

Figure 1. Distribution of restoration sites across the county of Coto Brus in southern Costa Rica.

1:150,000. For a few sites, photos from 1998 were used to fill in areas with shadows or clouds. The 1998 photos were collected from November 1997 to February 1998 at a scale of 1:40,0oo. Photos were orthorectified by Dr. David Morales and analyses were conducted with ArcGIS 9.I.

Primary and secondary forest and other non-forest land cover classes were identified and quantified manually, using texture characteristics and FAO guidelines (FAO 1998). Proportions of each class were calculated for $500 \mathrm{~m}$ buffers constructed around the centre of each treatment. Ground truth data were collected in mid-2007 and 2008 to check the classification of each polygon. When discrepancies were found, the classification was changed. We summed the proportions of the primary and secondary forest classes for each buffer and averaged these values for the three buffers per site to arrive at one value. We classified each site as having sparse $(10-26 \%, n=4)$, or moderate $(34-76 \%, n=6)$ landscape forest cover.

\section{Analysis of individual species captures}

The number of captures per net hour of each species was calculated for each site/treatment/ sampling round combination and used as the response variable in mixed model analyses, 
conducted with the Glimmix procedure in SAS 9.1.3 (SAS Institute 2002-2003) which can incorporate both random and fixed effects.

For the warbler species, treatment (plantation, island, or control), season (November, February, or April), vegetation height (high or low), and landscape forest cover (sparse or moderate) were fixed factors. Swainson's Thrushes were captured primarily in April (77 of 79 captures) so we excluded season from this species' model and included only April captures in analyses. We identified potentially important interactions between fixed effect variables with two-way contingency table analyses. Sample sizes limited the power to detect three-way interactions. Cell frequencies were the number of captures of a species for each two-variable combination, adjusted for sampling effort (Sokal and Rohlf 1995). Interactions that were significant at the $P<$ 0.05 level were included as fixed factors in global models. A repeated measures factor was used in all models because sites were sampled multiple times. Site was included as a random factor for all species.

In addition to the global models, we tested a nested subset of models for each species. Nested models were chosen based on the $P$-values for each factor in the model above it in the hierarchy. The factor with the highest $P$-value was excluded from the next nested model.

We chose the best model for each species and each dataset by calculating the difference in chisquare values for pairs of nested models. If the difference in the chi-square values is significant, the model with more variables explains the response variable significantly better than the model with fewer variables (Stevens 2002). We tested for significant differences between classes within variables using the Contrast statement which computes an F statistic based on a matrix associated with the fixed and random effects of the model (SAS Institute 2006).

\section{Migrant classification}

Migrant species were classified according to relative use of open habitats and woody substrates on wintering grounds, based on previous descriptions (Lynch 1989, Stiles and Skutch 1989, Greenberg 1992b, Lynch 1992, Petit et al. 1992, Powell et al. 1992, Robbins et al. 1992, Greenberg et al. 1997, Johnson et al. 2006). The first category (open) included species that primarily use open habitat and little woody vegetation, the second (mixed) included species that use both open and forested habitats and woody substrates, and the third (woody) included species that primarily use forested habitats and woody vegetation.

\section{Results}

\section{Focal species}

Chestnut-sided Warblers, Swainson's Thrushes, and Tennessee Warblers were captured significantly more often in plantations than islands or controls (Tables $I$ and 2). Capture numbers in islands and controls were not significantly different for Swainson's Thrushes and Tennessee Warblers. Season significantly influenced Tennessee Warblers captures; only $11 \%$ were in April. The Mourning Warbler was the only species for which vegetation height was a significant positive influence (Tables 1 and 2). Landscape forest cover did not influence captures of any species.

\section{Migrant assemblage patterns}

We captured 478 migrants of 25 species during 3,858 mist-net hours. The fewest captures occurred in control treatments $(15.7 \%), 26.6 \%$ were in islands, and $57.7 \%$ were in plantations. Fifteen species were captured in the controls, 19 species in the islands, and 24 species in the plantations (Table 3). Species classified in the open category were captured in controls 29 times, in islands 39 times, and in plantations 40 times. Species in the mixed category were captured more frequently in plantations (63.0\% of captures) than islands (24.1\%) or controls (12.9\%, $n=349)$. 
Table 1. Final models for captures of four Neotropical migrant species sampled during the non-breeding season in southern Costa Rica, 2006-2008.

\begin{tabular}{llccrr}
\hline Species & Variable(s) & $n^{*}$ & Den $d f^{* *}$ & $F$ & $P$ \\
\hline Chestnut-sided Warbler & Treatment & 261 & 219 & 22.4 & $<0.001$ \\
Mourning Warbler & Veg. Height & 261 & 219 & 9.5 & 0.002 \\
Swainson's Thrush & Treatment & 81 & 39 & $5 \cdot 5$ & 0.008 \\
& Season & & 217 & $5 \cdot 5$ & 0.005 \\
Tennessee Warbler & Treatment & 261 & 217 & 7.0 & 0.001 \\
\hline
\end{tabular}

* Sample size is the sum of the number of sites multiplied by the number of times each site was sampled, multiplied by the number of treatments. The sample size is lower for the Swainson's Thrush than for the other species because we used data only from the two April sampling periods, as explained in the Methods.

${ }^{* *}$ The denominator $d f$ used in the calculation of the F-statistic is computed with the containment technique (SAS Institute 2006) that will vary with different response and explanatory variables.

Species in the woody category were captured most frequently in plantations $(76.2 \%$ of captures), and less frequently in islands $(19.0 \%)$ or controls $(4.8 \%, n=21$, Table 3$)$.

Three species on the Birds of Conservation Concern List (U.S. Fish and Wildlife Service 2008) were captured: Golden-winged Warbler Vermivora chrysoptera, Worm-eating Warbler Helmitheros vermivorus, and Kentucky Warbler Oporornis formosus (Table 3).

\section{Recaptures}

Chestnut-sided Warblers were recaptured 16 times (12 individuals). Mourning Warblers were recaptured 16 times ( 13 individuals) and Tennessee Warblers six times (six individuals). Swainson's Thrushes were never recaptured. No individuals were recaptured in a different site from where they were originally captured. The majority of Chestnut-sided, Mourning, and Tennessee Warbler recaptures were within the same treatments where they were originally captured $(70.6 \%, 81.3 \%$, and $50 \%$ respectively). The majority of Chestnut-sided Warbler recaptures were of birds captured and recaptured in plantations, as were half of Tennessee Warbler recaptures. Mourning Warbler captures and recaptures were more mixed by treatment. Approximately one third of Chestnut-sided Warbler recaptures were across winters as were one quarter of Mourning Warbler recaptures. One half of Tennessee Warbler recaptures were across winters.

\section{Discussion}

\section{Treatment and vegetation height effects}

Increasing interest and effort in tropical forest restoration (Chazdon 2008) provide the opportunity to improve limited knowledge of migrant wintering habitat use (Faaborg et al. 2010). As predicted, captures for Chestnut-sided Warblers, Tennessee Warblers and Swainson's Thrushes, all species that use woody vegetation, were significantly higher in plantation treatments than other treatments. We captured other migrant species in lower numbers, precluding statistical analyses. These data indicate a similar positive effect of plantation-style planting for species including Yellow-bellied Flycatcher Empidonax flaviventris, Wilson's Warbler Wilsonia pusilla and Philadelphia Vireo Vireo philadelphicus. For others, like Rose-breasted Grosbeak Pheucticus ludovicianus, captures were approximately equal in all treatments. No species appeared to prefer control or island treatments, indicating that plantations did not deter species that use non-woody vegetation, at least at this stage of recovery (within $1-4$ years of planting). In addition, more migrant species were captured in plantations compared to the other treatments and captures of migrants classified in the woody category were concentrated in plantations. We 
Table 2. Variable estimates in final models for four wintering Neotropical migrant species, based on mist-net captures.

\begin{tabular}{|c|c|c|c|c|c|c|}
\hline Species & Variable & Class & $\begin{array}{l}\text { Number } \\
\text { captures } \\
\text { per 10o } \\
\text { net } \\
\text { hours }\end{array}$ & Estimate $^{*}$ & Standard Error & $P^{* *}$ \\
\hline \multirow{4}{*}{$\begin{array}{l}\text { Chestnut- } \\
\text { sided } \\
\text { Warbler }\end{array}$} & \multirow[t]{4}{*}{ Treatment } & Intercept & & 0.562 & 0.069 & $<0.001$ \\
\hline & & Control & 0.1 & -0.555 & 0.084 & $<0.001$ \\
\hline & & Island & 0.9 & -0.372 & 0.084 & $<0.001$ \\
\hline & & Plantation & 4.2 & o & & \\
\hline \multirow{3}{*}{$\begin{array}{l}\text { Mourning } \\
\text { Warbler }\end{array}$} & \multirow{3}{*}{$\begin{array}{l}\text { Veg. } \\
\text { Height }\end{array}$} & Intercept & & 0.244 & 0.081 & 0.011 \\
\hline & & High & $4 \cdot 5$ & 0.453 & 0.147 & 0.002 \\
\hline & & Low & 1.6 & $\mathrm{o}$ & & \\
\hline \multirow{4}{*}{$\begin{array}{c}\text { Swainson's } \\
\text { Thrush }\end{array}$} & \multirow[t]{4}{*}{ Treatment } & Intercept & & 2.015 & 0.399 & $<0.001$ \\
\hline & & Control & 0.7 & -1.666 & 0.537 & 0.004 \\
\hline & & Island & 1.2 & -1.387 & 0.537 & 0.014 \\
\hline & & Plantation & 4.1 & o & & \\
\hline \multirow{8}{*}{$\begin{array}{l}\text { Tennessee } \\
\text { Warbler }\end{array}$} & \multirow[t]{4}{*}{ Season } & Intercept & & 0.764 & 0.131 & $<0.001$ \\
\hline & & April & 0.9 & -0.362 & 0.127 & 0.005 \\
\hline & & February & 3.4 & -0.012 & 0.121 & 0.923 \\
\hline & & November & $3 \cdot 3$ & o & & \\
\hline & \multirow[t]{4}{*}{ Treatment } & Intercept & & 0.764 & & \\
\hline & & Control & 1.4 & -0.443 & 0.125 & $<0.001$ \\
\hline & & Island & 2.0 & -0.353 & 0.125 & 0.005 \\
\hline & & Plantation & $4 \cdot 4$ & $\mathrm{o}$ & & \\
\hline
\end{tabular}

"The Intercept estimates represent the additive effects of the intercepts and the effects of the classes with zeroes, e.g. in the case of Chestnut-sided Warblers the intercept estimate is the additive effect of the intercept and the plantation class. The other estimates (for control, island, April, and February classes) are the differences between the effects of these classes and the intercept plus plantation or plus November effect within a species. ${ }^{* *}$ The $P$-values show whether there were significant differences between the class and the intercept plus plantation or intercept plus November effect. For example, for the Tennessee Warbler, the number of captures was significantly different between April and November but not between February and November.

emphasise that the restoration treatments are young and that, at the current stage, likely do not provide optimal habitat for most migrants. However, the results indicate that planting seedlings in plantations, rather than islands, more rapidly converts pasture into usable habitat for a variety of migrant species.

The number of migrant species and individuals captured in islands was greater than in controls, indicating that planting in islands produced habitat that was perceived by some migrant species as more attractive than controls, which were similar to active and recently abandoned pasture. This result provides some support for the idea that island planting may be a useful alternative to plantation-style planting (Rey Benayas et al. 2008), particularly when financial resources are limited. However, our results do not support the idea that islands are as ecologically effective in providing migrant habitat, at least at this stage in the restoration process. Plantation planting appeared to more quickly jump-start the process of developing migrant habitat although areas planted in islands may rapidly catch up.

Vegetation height influenced capture rates only of Mourning Warblers. Mourning Warblers use scrubby winter habitats (Stiles and Skutch 1989) so it is somewhat surprising that they were more abundant in high-vegetation sites, which we classified based on woody vegetation. However, high-vegetation sites (all planted in 2004) also had the densest non-woody understorey in the last 
Table 3. Number of times individual migrant species were captured during the wintering season in southern Costa Rica, 2006-2008, in different planting treatments.

\begin{tabular}{|c|c|c|c|c|c|c|}
\hline \multirow[t]{2}{*}{ Scientific name } & \multirow[t]{2}{*}{ Common name } & \multirow[t]{2}{*}{ Family } & \multirow{2}{*}{$\begin{array}{l}\text { Winter habitat } \\
\text { classification* }\end{array}$} & \multicolumn{3}{|c|}{ Treatment $^{* *}$} \\
\hline & & & & Con & Isl & Plan \\
\hline $\begin{array}{c}\text { Archilochus } \\
\text { colubris }\end{array}$ & $\begin{array}{l}\text { Ruby-throated } \\
\text { Hummingbird }\end{array}$ & Trochilidae & mixed & 2 & $\mathrm{o}$ & 2 \\
\hline $\begin{array}{l}\text { Contopus } \\
\text { sordidulus/virens }\end{array}$ & $\begin{array}{c}\text { Western/Eastern } \\
\text { Wood-Pewee }\end{array}$ & Tyrannidae & mixed & 1 & 1 & 2 \\
\hline $\begin{array}{l}\text { Empidonax } \\
\text { flaviventris }^{* * *}\end{array}$ & $\begin{array}{l}\text { Yellow-bellied } \\
\text { Flycatcher }\end{array}$ & Tyrannidae & mixed & 5 & 9 & 22 \\
\hline Vireo flavifrons & $\begin{array}{l}\text { Yellow-throated } \\
\text { Vireo }\end{array}$ & Vireonidae & mixed & 1 & 1 & 4 \\
\hline $\begin{array}{l}\text { Vireo } \\
\quad \text { philadelphicus }\end{array}$ & $\begin{array}{l}\text { Philadelphia } \\
\text { Vireo }\end{array}$ & Vireonidae & mixed & $\mathrm{o}$ & 1 & 6 \\
\hline Vireo olivaceus & Red-eyed Vireo & Vireonidae & mixed & 1 & 1 & 1 \\
\hline Hirundo rustica & Barn Swallow & Hirundinidae & open & 1 & $\mathrm{o}$ & $\mathrm{o}$ \\
\hline Catharus ustulatus & $\begin{array}{c}\text { Swainson's } \\
\text { Thrush }\end{array}$ & Turdidae & mixed & 10 & 15 & 54 \\
\hline $\begin{array}{l}\text { Vermivora } \\
\text { chrysoptera }\end{array}$ & $\begin{array}{l}\text { Golden-winged } \\
\text { Warbler }\end{array}$ & Parulidae & mixed & 2 & 1 & 5 \\
\hline $\begin{array}{l}\text { Vermivora } \\
\text { peregrina }\end{array}$ & $\begin{array}{l}\text { Tennessee } \\
\text { Warbler }\end{array}$ & Parulidae & mixed & 18 & 26 & 56 \\
\hline $\begin{array}{r}\text { Dendroica } \\
\text { petechia }\end{array}$ & Yellow Warbler & Parulidae & open & o & 3 & 1 \\
\hline $\begin{array}{l}\text { Dendroica } \\
\text { pensylvanica }\end{array}$ & $\begin{array}{l}\text { Chestnut-sided } \\
\text { Warbler }\end{array}$ & Parulidae & mixed & 1 & 17 & 48 \\
\hline Dendroica virens & $\begin{array}{l}\text { Black-throated } \\
\text { Green Warbler }\end{array}$ & Parulidae & woody & $\mathrm{o}$ & $\mathrm{o}$ & 1 \\
\hline Dendroica fusca & $\begin{array}{l}\text { Blackburnian } \\
\text { Warbler }\end{array}$ & Parulidae & woody & o & 2 & 7 \\
\hline Setophaga ruticilla & $\begin{array}{l}\text { American } \\
\text { Redstart }\end{array}$ & Parulidae & woody & $\mathrm{o}$ & $\mathrm{o}$ & 1 \\
\hline $\begin{array}{l}\text { Helmitheros } \\
\text { vermivorum }\end{array}$ & $\begin{array}{c}\text { Worm-eating } \\
\text { Warbler }\end{array}$ & Parulidae & woody & o & o & 1 \\
\hline $\begin{array}{l}\text { Seiurus } \\
\quad \text { aurocapilla }\end{array}$ & Ovenbird & Parulidae & woody & $\mathrm{o}$ & 1 & 1 \\
\hline $\begin{array}{l}\text { Parkesia } \\
\quad \text { noveboracensis }\end{array}$ & $\begin{array}{l}\text { Northern } \\
\text { Waterthrush }\end{array}$ & Parulidae & woody & 1 & 1 & 4 \\
\hline $\begin{array}{l}\text { Oporornis } \\
\text { formosus }\end{array}$ & $\begin{array}{l}\text { Kentucky } \\
\text { Warbler }\end{array}$ & Parulidae & woody & $\mathrm{o}$ & o & 1 \\
\hline $\begin{array}{l}\text { Oporornis } \\
\text { philadelphia }\end{array}$ & $\begin{array}{l}\text { Mourning } \\
\text { Warbler }\end{array}$ & Parulidae & open & 27 & 33 & 38 \\
\hline Wilsonia pusilla & $\begin{array}{l}\text { Wilson's } \\
\text { Warbler }\end{array}$ & Parulidae & mixed & 2 & 5 & 15 \\
\hline Piranga rubra & Summer Tanager & Cardinalidae & mixed & o & 1 & 2 \\
\hline $\begin{array}{l}\text { Pheucticus } \\
\text { ludovicianus }\end{array}$ & $\begin{array}{c}\text { Rose-breasted } \\
\text { Grosbeak }\end{array}$ & Cardinalidae & mixed & 2 & 3 & 2 \\
\hline Passerina cyanea & Indigo Bunting & Cardinalidae & open & 1 & 3 & 1 \\
\hline Icterus galbula & Baltimore Oriole & Icteridae & mixed & o & 3 & 1 \\
\hline Totals & & & & 75 & 127 & 276 \\
\hline
\end{tabular}

*Species were classified based on previous descriptions of their wintering habitats and substrates (see references in Methods section). Open = species that primarily use open habitat and little woody vegetation, mixed = species that use both open and forested habitats and woody substrates, woody $=$ species that primarily use forested habitats and woody vegetation (Table 3 ).

${ }^{* *}$ Con $=$ Control, Isl = Island, Plan = Plantation.

***The majority of individuals were Empidonax flaviventris. A few individuals were difficult to identify definitively. 
year of the study, because of the cessation of clearing, apparently making them more attractive to Mourning Warblers. We do not suggest there was no influence of vegetation height on the other species; three of the low sites had few captures. However, the focal species were captured in sites from both of the height categories. This variability may have obscured other patterns.

\section{Landscape and seasonal effects}

Landscape forest cover did not influence capture rates of any of the focal species. The focal species may be flexible enough to use or, at least, pass through the land cover types in the study region. In addition, there may be enough arboreal features (Sekercioglu et al. 2007), even in low forest cover landscapes, to support the movements of species like Chestnut-sided Warblers.

Swainson's Thrushes showed a strong pattern as a passage migrant in April. Tennessee Warblers were infrequently captured in April, the majority apparently having already left the study region to begin their migration north. These patterns seem to reflect large-scale movements and species-specific timing of migration, rather that responses to local-scale conditions.

The capture results do not take into account potential differences in detectability in the different planting designs. However, observational data also suggested that controls were used infrequently by migrants (Lindell unpubl. data) and we expected mist-net captures to be at least as likely in control treatments as the other treatments, given the relatively low lack of cover and thus impetus to move. Thus, our results are likely to be conservative with regard to the greater use of plantations by migrants.

\section{Value of restoration sites}

Restoration studies commonly involve planting plots of the sizes considered in this study (e.g. Chapman and Chapman 1999, Zahawi and Augspurger 2006) and birds exhibit preferences and differential use of patches of habitat at this and smaller scales (Suhonen 1993, Butler et al. 2005, Fink et al. 2009, Leyequién et al. 2010). The recapture data indicate that, for the warbler species, individuals were not merely passing through the planting treatments but using them regularly, with a number of individuals returning to the same treatments in consecutive years. Thus, although the restoration sites likely do not represent the entire foraging range of individual wintering migrants, the availability of restored habitat patches may influence how long and to what extent migrants use a larger wintering area. Our results indicate that 1 ) planting even relatively small areas with woody seedlings increases the usability of a site for many wintering migrants and 2) planting areas continuously, plantation-style, further enhances the attractiveness of sites to species that use woody vegetation. Thus, we recommend plantation-style planting if the majority of migrant species of conservation concern in an area use woody vegetation. Island planting is a less ecologically effective, although more cost-effective, alternative that provides usable habitat for a range of migrant species early in the restoration process. These types of planting should be considered within the context of region-wide strategies to enhance habitat for wintering migrants. Future work including migrant demographic measures would enhance our understanding of the relative value of different restoration planting designs (Johnson et al. 2006).

\section{Acknowledgements}

The Neotropical Migratory Bird Conservation Act Program of the U.S. Fish and Wildlife Service provided funding for the work. The Earthwatch Institute and the National Science Foundation (grant DEB 05-15577) funded set-up and maintenance of the sites. We thank Juan Abel Rosales, Kener Alvarez, Roger Mendez, Jeisson Figueroa, Allen Imana, and Pablo Rosales for field assistance. We thank the landowners who allowed us to work on their property. Emily Cohen, Sara Kaiser, Dan Linden, and Sam Riffell provided valuable comments on the manuscript. 


\section{References}

Butler, S. J., Whittingham, M. J., Quinn, J. L. and Cresswell, W. (2005) Quantifying the interaction between food density and habitat structure in determining patch selection. Anim. Behav. 69: 337-343.

Chapman, C. A. and Chapman, L. J. (1999) Forest restoration in abandoned agricultural land: a case study from East Africa. Conserv. Biol. 13: 1301-11.

Chazdon, R. L. (2008) Beyond deforestation: restoring forests and ecosystem services on degraded lands. Science 320: 1458-1460.

Dirzo, R. and Raven, P. H. (2003) Global state of biodiversity and loss. Annu. Rev. Environ. Resour. 28: 137-167.

Estrada, A., Coates-Estrada, R. and Meritt, D. A. Jr. (1997) Anthropogenic landscape changes and avian diversity at Los Tuxtlas, Mexico. Biodivers. Conserv. 6: 19-43.

Faaborg, J., Holmes, R. T., Anders, A. D., Bildstein, K. L., Dugger, K. M., Gauthreaux, S. A., Jr., Heglund, P., Hobson, K. A., Jahn, A. E., Johnson, D. H., Latta, S. C., Levey, D. J., Marra, P. P., Merkord, C. L., Nol, E., Rothstein, S. I., Sherry, T. W., Sillett, T. S., Thompson, F. R. III and Warnock, N. (2010) Recent advances in understanding migration systems of New World land birds. Ecol. Monogr. 8o: 3-48.

FAO (Food and Agriculture Organization of the United Nations) (1998) Appendix 1: Definitions as in Forest Resources Assessment Working Paper 1 and comments Downloaded from http://www.fao.org/ docrep/oo6/ad665e/ad665eo6.htm 5 April 2009.

FAO (Food and Agriculture Organization of the United Nations) (2005) Global forest resources assessment 2005: Progress towards sustainable forest management. Rome, Italy: FAO.

Fink, R. D., Lindell, C. A., Morrison, E. B., Zahawi, R. A. and Holl, K. D. (2009) Patch size and tree species influence the number and duration of bird visits in forest restoration plots in southern Costa Rica. Restor. Ecol. 17: 479-486.

Greenberg, R. (1992a) The nonbreeding season: Introduction. Pp. $175-177$ in J. M. Hagan III and D. W. Johnston, eds. Ecology and conservation of Neotropical migrant landbirds. Washington DC: Smithsonian Institution Press.

Greenberg, R. (1992b) Forest migrants in non-forest habitats on the Yucatan Peninsula. Pp. $273-286$ in J. M. Hagan III and D. W. Johnston, eds. Ecology and conservation of Neotropical migrant landbirds. Washington DC: Smithsonian Institution Press.

Greenberg, R., Bichier, P. and Sterling, J. (1997) Bird populations in rustic and planted shade coffee plantations of eastern Chiapas, Mexico. Biotropica 29: 501-514.

Holl, K. D., Zahawi, R. A., Cole, R. J., Ostertag, R. and Cordell, S. (2011) Planting seedlings in plantations versus tree islands as a large-scale tropical forest restoration strategy. Restor. Ecol. 19: 470-479.

Holmes, R. T. (2007) Understanding population change in migratory songbirds: longterm and experimental studies of Neotropical migrants in breeding and wintering areas. Ibis 149 (Suppl. 2): 2-13.

Hutto, R. L. (1985) Habitat selection by nonbreeding, migratory land birds. Pp. 455476 in M. L. Cody, ed. Habitat selection in birds. Orlando, Florida, USA: Academic Press.

Johnson, M. D., Sherry, T. W., Holmes, R. T. and Marra, P. P. (2006) Assessing habitat quality for a migratory songbird wintering in natural and agricultural habitats.

Conserv. Biol. 20: 1433-1444.

Kirby, J. W., Stattersfield, A. J., Butchart, S. H. M., Evans, M. I., Grimmett, R. F. A., Jones, V. R., O'Sullivan, J., Tucker, G. M. and Newton, I. (2008) Key conservation issues for migratory land- and waterbird species on the world's major flyways. Bird Conserv. Int. 18 (Suppl. 1): S49-S73.

Lamb, D., Erskine, P. D. and Parrotta, J. A. (2005) Restoration of degraded tropical forest landscapes. Science 310: 1628-1632.

Leyequién, E., de Boer, W. F. and Toledo, V. M. (2010) Bird community composition in a shaded coffee agro-ecological matrix in Puebla, Mexico: the effects of landscape heterogeneity at multiple spatial scales. Biotropica 42: 236-245. 
Lindenmayer, D. B., Knight, E. J., Crane, M. J., Montague-Drake, R., Michale, D. R. and MacGregor, C. I. (2010) What makes an effective restoration planting for woodland birds? Biol. Conserv. 143: 289-301.

Lynch, J. F. (1989) Distribution of overwintering Nearctic migrants in the Yucatan Peninsula, I: General patterns of occurrence. Condor 91: 515-544.

Lynch, J. F. (1992) Distribution of overwintering Nearctic migrants in the Yucatan Peninsula, II: use of native and humanmodified vegetation. Pp. 178-196 in J. M. Hagan III and D. W. Johnston, eds. Ecology and conservation of Neotropical migrant landbirds. Washington, DC: Smithsonian Institution Press.

Mack, D. E., and Wang, Y. (200o) Swainson's Thrush (Catharus ustulatus). In A. Poole, ed. The birds of North America online. Ithaca, New York, USA: Cornell Lab of Ornithology. Downloaded from http://bna.birds.cornell. $\mathrm{edu} / \mathrm{bna} / \mathrm{species} / 540$ I April 2009.

Morrison, E. B., Lindell, C. A., Holl, K. D. and Zahawi, R. A. (2010) Using behavioural ecology to assess the quality of tropical forest restoration sites: patch size effects on avian foraging patterns. J. Appl. Ecol. 47: 130-138.

Newton, I. (2004) Population limitation in migrants. Ibis 146: 197-226.

Norris, D. R., Marra, P. P., Kurt, T. K., Sherry, T. W. and Ratcliffe, L. M. (2004) Tropical winter habitat limits reproductive success on the template breeding grounds in a migratory bird. P. Roy. Soc. Lond. B Biol. 271: 59-64.

Petit, D. R., Petit, L. J. and Smith, K. G. (1992) Habitat associations of migratory birds overwintering in Belize, Central America. Pp. $247-256$ in J. M. Hagan III and D. W. Johnston, eds. Ecology and conservation of Neotropical migrant landbirds. Washington, DC: Smithsonian Institution Press.

Powell, G. V. N., Rappole, J. H. and Sader, S. A. (1992) Neotropical migrant landbird use of lowland Atlantic habitats in Costa Rica: A test of remote sensing for identification of habitat. Pp. $287-298$ in J. M. Hagan III and D. W. Johnston, eds. Ecology and conservation of Neotropical migrant landbirds. Washington, DC: Smithsonian Institution Press.
Reid, J. L., Harris, J. B. C., Martin, L. J., Barnett, J. R. and Zahawi, R. A. (2008) Distribution and abundance of nearcticneotropical songbird migrants in a forest restoration site in southern Costa Rica. J. Trop. Ecol. 24: 685-688.

Rey Benayas, J. M., Bullock, J. M. and Newton, A. C. (2008) Creating woodland islets to reconcile ecological restoration, conservation, and agricultural land use. Front. Ecol. Environ. 6: 329-336.

Richardson, M., and Brauning, D. W. (1995) Chestnut-sided warbler (Dendroica pensylvanica). In A. Poole, ed. The birds of North America online. Ithaca, New York, USA: Cornell Lab of Ornithology. Downloaded from http://bna.birds.cornell.edu/bna/species/ 190 I April 2009.

Robbins, C. S., Sauer, J. R., Greenberg, R. S. and Droege, S. (1989) Population declines in North American birds that migrate to the Neotropics. Proc. Natl. Acad. Sci. USA. 86: $7658-7662$.

Robbins, C. S., Dowell, B. A., Dawson, D. K., Colón, J. A., Estrada, R., Sutton, A., Sutton, R. and Weyer, D. (1992) Comparison of Neotropical migrant landbird populations wintering in tropical forest, isolated forest fragments, and agricultural habitats. Pp. 207-22O in J. M. Hagan, III and D. W. Johnston, eds. Ecology and conservation of Neotropical migrant landbirds. Washington, DC: Smithsonian Institution Press.

Robinson, G. R. and Handel, S. N. (2000) Directing spatial patterns of recruitment during an experimental urban woodland reclamation. Ecol. Applic. 10: 174-188.

SAS Institute (2006) Glimmix procedure documentation. Cary, North Carolina, USA: SAS Institute Inc.

SAS Institute (2002-2003) SAS 9.1.3. Cary, North Carolina, USA: SAS Institute Inc.

Sauer, J. R., Hines, J. E. and Fallon, J. (2008) The North American breeding bird survey, results and analysis 1966-2007. Version 5.15. Downloaded from http://www.mbr-pwrc.usgs.gov/ $\mathrm{bbs} / \mathrm{trend} / \mathrm{tfo} \cdot \mathrm{html}$ on 3 April 2009.

Sekercioglu, C. H., Loarie, S. R., Brenes, F. O., Ehrlich, P. R. and Daily, G. C. (2007) Persistence of forest birds in the Costa Rica agricultural countryside. Conserv. Biol. 21: 482-494. 
Sokal, R. R. and Rohlf, F. J. (1995) Biometry: The principles and practice of statistics in biological research. New York, USA: W. H. Freeman \& Co.

Stevens, J. (2002) Applied multivariate statistics for the social sciences, $4^{\text {th }}$ edition. Mahwah, New Jersey, USA: Lawrence Erlbaum Associates.

Stiles, F. G. and Skutch, A. F. (1989) A guide to the birds of Costa Rica. Ithaca, New York, USA: Comstock Publishing Associates.
Suhonen, J. (1993) Predation risk influences the use of foraging sites by tits. Ecology 74 : 1197-1203.

US Fish and Wildlife Service (2008) Birds of conservation concern 2008. USFWS Division of Migratory Bird Management. Downloaded from http://www.fws.gov/migratorybirds/ on I July 2009.

Zahawi, R. A. and Augspurger, C. K. (2006) Tropical forest restoration: tree islands as recruitment foci in degraded lands of Honduras. Ecol. Applic. 16: 464-478.

\section{CATHERINE A. LINDELL*}

Zoology Department/Center for Global Change and Earth Observations, Michigan State University, 1405 S. Harrison Rd., East Lansing, Michigan 48823, USA

\section{REBECCA J. COLE}

Environmental Studies Department, University of California, Santa Cruz, California 95064, USA

Current address: Department of Natural Resources, University of Hawaii at Manoa, Hilo, Hawaii 96822, USA

\section{KAREN D. HOLL}

Environmental Studies Department, University of California, Santa Cruz, California 95064, USA

\section{RAKAN A. ZAHAWI}

Las Cruces Biological Station, Organization for Tropical Studies, San Vito, Costa Rica

*Author for correspondence; e-mail: lindellc@msu.edu 